\title{
Multiple casualties caused by a gale
}

\author{
R. N. ILLINGWORTH AND KAREN A. ILLINGWORTH
}

Accident and Emergency Departments, St fames's University Hospital, Leeds

\section{SUMMARY}

On 1 February 1983 severe westerly gales affected most of Britain. In Leeds wind speeds of up to $96 \mathrm{mph}$ ( $43 \mathrm{metres} / \mathrm{sec}$ ) were reported, 116 patients were treated in hospital for injuries caused by the wind and three people died. The majority of accidents occurred when people were blown over whilst walking outside. These might have been avoided had people been warned to stay inside.

\section{INTRODUCTION}

Severe weather conditions may cause accidents and serious injuries. Injuries due to high winds are uncommon in Britain, especially inland. We report the injuries caused by the wind on a day of unusually strong gales.

\section{PATIENTS AND METHODS}

The Accident and Emergency Departments of Leeds General Infirmary and St James's University Hospital serve a population of about 735000 in and around Leeds. We studied patients attending these hospitals with injuries caused directly or indirectly by the wind on 1 February 1983. Details of the patients' accidents and injuries were obtained from their hospital records.

Information about wind speeds was obtained from the Meteorological Offices at Bawtry (Doncaster) and Bracknell (Berkshire) and from local newspapers. No official wind measurements were taken in Leeds but continuous wind speed records were available from anemographs at Wilsden (13 miles, $21 \mathrm{~km}$, west of Leeds) and Church Fenton ( 13.5 miles, $22 \mathrm{~km}$, east of Leeds). Intermittent recordings were also available from Leeds Airport (6 miles, $10 \mathrm{~km}$, north-west of Leeds).

Correspondence: $\operatorname{Dr}$ R. N. Illingworth, Accident and Emergency Department, St fames's University Hospital, Leeds LS $97 T F$ 


\section{RESULTS}

\section{Wind Speeds}

During the morning of 1 February 1983 westerly gale-force winds were recorde $\overrightarrow{\mathrm{w}_{0}}$ throughout the region. At Church Fenton the highest hourly mean speed of $46 \mathrm{mph}(2 \overrightarrow{\mathrm{b}}$ metres/sec) was recorded between 8 and $9 \mathrm{am}$, with a maximum gust of $79 \mathrm{mph}$ (3). metres $/ \mathrm{sec}$ ) at $9 \mathrm{am}$. A gust of $85 \mathrm{mph}(38 \mathrm{metres} / \mathrm{sec})$ was recorded at Leeds Airport and gusts up to $96 \mathrm{mph}$ (43 metres/sec) were reported in Leeds (Anon., 1983).

\section{Patients}

One hundred and sixteen patients attended with wind injuries sustained on 1 Februar $\stackrel{\mathbb{D}}{\mathbb{B}}$ 1983. One hundred and four patients came on that day (23\% of new patients attending) $\overrightarrow{\vec{s}}$ 76 of these patients arrived between 9 am and 12 noon. The remaining 12 patient 8 first attended over the succeeding nine days. The patients' ages are shown in Table $1_{0}^{J}$ Forty-six patients were male.

Table 1



\section{Mechanism of Injury}

Eighty-one patients were blown over, 77 of them while walking outside. One person waş in a caravan which blew over and one in a push-chair. One man was blown off a roof and another, who later died, was blown off a ladder.

Nine people were injured when parts of buildings collapsed. These included roof (causing one fatality), a door, a wall and a chimney. Four of these nine people were inside the buildings. Four patients were injured by falling slates and twelve by other falling of flying objects, including window glass, a tree, a milk-crate and a dust-bin. Two childremu were hurt by swinging doors. Three people were injured while clearing away brokete glass and one lady tripped over wreckage after her roof had collapsed.

Four patients were injured in road accidents caused by the wind. One man died immediately when his car was crushed by a falling tree. A lorry blew over injuring tw $\Theta^{+}$ occupants and a car crashed after the driver's vision was obscured by a flying tarpaulin 


\section{Injuries and Treatment}

The patients sustained injuries of all degrees of severity (Table 2). Fourteen of the 27 patients with fractures or dislocations were aged 60 or more.

Seventy-four patients required radiological investigation. Twenty-eight patients were sutured and 11 had fractures or dislocations manipulated in the accident and emergency departments. Forty-nine patients were discharged after their first attendance and 53 were reviewed in out-patient clinics.

Thirteen patients required admission. Two patients with severe head injuries were resuscitated and ventilated in the accident and emergency departments but died later in hospital. One man was dead on arrival at hospital after sustaining severe injuries to his chest and back.

Both accident and emergency departments were very busy but no extra staff were called in.

Table 2 Injuries caused by the wind (Some patients sustained more than one injury)

\begin{tabular}{lcc}
\hline Crushed chest (multiple fractures) & & 1 (fatal) \\
Head injuries & 1 & 7 (2 fatal) \\
$\quad$ (with loss of consciousness) & 1 & 22 \\
Fractured skull & 1 & \\
Other fractures & 6 & \\
$\quad$ Facial bones & 8 & \\
Cervical spine & 2 & 3 \\
Shoulder & 4 & 9 \\
Wrist & & \\
Hip & & 39 \\
Hand or foot & 6 & \\
Dislocations (shoulder) & 3 & 39 \\
Sprains & & \\
$\quad$ Ankle & 27 & 32 \\
Other & 12 & \\
Lacerations & & \\
$\quad$ Head & 12 & \\
Limbs & 27 & \\
Abrasions & & \\
$\quad$ Head & 13 & \\
Limbs & 14 & \\
Contusions & 5 & \\
Head & & \\
Limbs & & \\
Chest & & \\
Eye injuries & & \\
Other injuries & & \\
\hline
\end{tabular}




\section{DISCUSSION}

The work of accident and emergency departments may be affected considerably by the्ठ weather. For example snow and ice may greatly increase the incidence of falls and? fractures. (Ralis, 1981). Multiple casualties may also result from high winds, as in this study. Gale force winds are quite common in Britain but it is unusual to see so many patient? with injuries resulting from the wind.

Wind injuries are relatively common in countries where tornadoes and hurricanes occur. For example in the United States such storms cause an average of about 200 death per year and occasionally more than 300 deaths in a day (Anon., 1974). A tornado which struck Topeka, Kansas in 1966 injured 400 people and caused 12 deaths, mostly from $P$ head and chest injuries, but many more injuries were avoided because of radio an $\rightleftarrows_{\omega}$ television warnings advising people to take shelter before the disaster (Beelman, 1967) $\frac{\curvearrowright}{\Phi}$

In Leeds accidents caused by the wind killed three people and many more were luckye. to escape without fatal injuries. Some of our patients' accidents seemed unavoidable in ${ }_{-}$ the circumstances. However many injuries could have been prevented, especially iff elderly people had stayed indoors for a few hours until the very high winds had abated. Ab few people sustained injury while indoors but many more while outside, most being blown over or hit by flying objects. It was clear that many people had underestimated the strength of the wind.

Warning broadcasts on local radio and television services should help to reduce the number of casualties when severe winds are likely to cause accidents. Much, however depends on each person's commonsense in recognizing and avoiding danger迎i situations. In regions where high winds are common people are likely to be more aware⿳亠丷厂 the potential dangers and may be less liable to injury in a gale.

\section{ACKNOWLEDGEMENTS}

We thank Dr I. D. Adams and Mr D. H. Wilson for comments on the manuscript and the Meteorological Offices at Bawtry and Bracknell for information about wind speeds 3 .

\section{REFERENCES}

Anon. (2 February 1983) Killer gales ravage Britain. Yorkshire Post, Leeds, p 16.

Anon. (1974) Mortality from tornadoes, hurricanes and floods. Statistical Bulletin of the Metropolitan Lif

Insurance Company, New York 55, 4-7.

Beelman F. C. (1967) Disaster planning: report of tornado casualties in Topeka. Fournal of the Kansas Medica Society 68, 153-61.

Ralis Z. A. (1981) Epidemic of fractures during period of snow and ice. British Medical fournal 282, 603-50 